BACKGROUND: Markers of an acute phase reaction, such as C-reactive protein (CRP) or tumor necrosis factor-alpha (TNF- $\alpha$ ) and interleukin (IL)-6, are predictive for cardiovascular morbidity and mortality in normal subjects and in chronic renal failure patients. In this study, we aimed to investigate serum TNF- $\alpha$, IL6, IL-10 and CRP levels in continuous ambulatory peritoneal dialysis (CAPD) and hemodialysis (HD) patients.

Materials and metbods: Serum levels of TNF- $\alpha$, IL-6, IL-10 and CRP levels were measured in 30 patients who were just diagnosed with end-stage renal failure and treated, with 16 CAPD (nine female, seven male) and $14 \mathrm{HD}$ (eight female, six male) patients, before CAPD or HD treatment and after 3 months from the beginning of CAPD or HD in patients with no clinical signs of infection. The control groups were 20 healthy persons of similar age and sex. Serum levels of TNF- $\alpha$, IL-6, IL-10 and CRP were measured by enzyme-linked immunosorbent assay in stable CAPD and HD patients and in healthy persons.

Results: The mean serum levels of TNF- $\alpha$, IL-6, IL-10 and CRP showed no significant differences between the CAPD and HD patients for the beginning values and the third month of treatment. However, serum TNF- $\alpha$, IL-6, IL-10 and CRP levels were higher than the control group in the CAPD and HD patients regarding the beginning values and the third month of treatment $(p<0.001)$.

Conclusions: CAPD and HD of the renal replacement therapy have no effects on serum CRP and cytokines.

\section{The effects of peritoneal dialysis and hemodialysis on serum tumor necrosis factor-alpha, interleukin-6, interleukin-10 and C-reactive-protein levels}

\author{
Ali Borazan 1,CA, Hasan Ustün², Yucel Ustundag ${ }^{3}$, \\ Selim Aydemir ${ }^{3}$, Taner Bayraktaroglu', \\ Mehmet Sert ${ }^{1}$ and Ahmet Yilmaz ${ }^{4}$
}

${ }^{1}$ Department of Internal Medicine, and ${ }^{3}$ Department of Gastroenterology, Zonguldak Karaelmas University Faculty of Medicine, Zonguldak Karaelmas Universitesi Tip Fakültesi, Iç Hastalıklari ABD 67600, Zonguldak, Turkey; ${ }^{2}$ Department of Medical Oncology, and ${ }^{4}$ Department of Nephrology, Kocaeli University Faculty of Medicine, Turkey

\author{
${ }^{\mathrm{CA}}$ Corresponding Author: \\ Tel: +903722610169 \\ Fax: +90372 2610155 \\ E-mail: aliborazan@mail.com
}

Key words: Peritoneal dialysis, Hemodialysis, C-reactive protein, Cytokines

\section{Introduction}

Cardiovascular diseases are the major reason for mortality and morbidity of patients with chronic renal failure (CRF). ${ }^{1}$ The cardiovascular death rate in CRF patients is predicted as $9 \%$ per year, being 10 -fold to 20-fold higher than the normal population., ${ }^{1,2} \mathrm{C}$ reactive protein (CRP) is an acute-phase protein whose synthesis in the liver is regulated by different cytokines. Serum levels of CRP in the absence of active disease are low, but can rise up to 1000-fold in patients with an inflammatory reaction. Besides being a marker of inflammation, CRP itself may have proinflammatory properties since it can activate the complement system. ${ }^{3}$

The inflammatory response is orchestrated by cytokines, especially tumor necrosis factor-alpha (TNF- $\alpha$ ) and interleukin (IL)-6. Both regulate the production of acute-phase proteins, have potent effects on lipid and carbohydrate metabolism, and are linked with an increased risk of coronary artery disease in subjects with normal renal function. ${ }^{3,4}$ Proinflammatory cytokines also regulate vascular adhesion. TNF- $\alpha$ in particular promotes the expression of soluble cell adhesion molecule (CAM) by endothelial cells. ${ }^{5}$ Furthermore, increased plasma levels of soluble CAM have been reported in CRF patients. ${ }^{6}$ Thus it is possible that cytokines could drive the increased levels of acute-phase proteins and soluble CAM observed in patients at risk of coronary artery disease.

Most of these studies were based on single-point measurements of CRP or IL-6 plasma levels, and mortality during subsequent years was linked to the initial value. This concept was chosen without any knowledge of the time-dependent changes in these markers even in the absence of an acute illness. Therefore, we investigated the patterns of CRP and some cytokines (TNF- $\alpha$, IL-6, IL-10) in selected groups of continuous ambulatory peritoneal dialysis (CAPD) and hemodialysis (HD) patients. 


\section{Research design and methods}

\section{Patients}

This study was carried out on 30 patients (17 female, 13 male) who were just diagnosed with end-stage renal failure. Sixteen patients (nine female, seven male) were treated with CAPD, and in 14 patients (eight female, six male) HD was performed. The control group consisted of 20 healthy persons (11 female, nine male) of similar age and sex. All participants gave written consent. Clinically unstable patients and those with tumors, inflammatory diseases, or those treated with immunosuppressives were excluded. No patient showed signs of inflammation or infection during the study period.

Ambulatory HD patients were hemodialyzed on hollow-fiber polysulfone membrane dialyzators with a $1.2 \mathrm{~m}^{2}$ surface area (Polysulfon UF 4.0; Hemoflow F5, Fresenius, Germany) with bicarbonate-containing solutions for $4 \mathrm{~h}$ three times weekly. Peritoneal dialysis solutions of 21 with $1.36 \%$, and when necessary $3.86 \%$, glucose were used three or four times a day by the patients using CAPD. All the patients received a chronic renal failure diet consisting of $35 \mathrm{kcal} / \mathrm{kg}$, including $1.2-1.4 \mathrm{~g} / \mathrm{kg}$ of protein, $1000-1500 \mathrm{mg}$ of calcium, $700 \mathrm{mg}$ of phosphorus and $250 \mathrm{mg}$ of magnesium, polyvitamins and recombinant human erythropoietin.

\section{Cytokines and CRP assays}

Blood samples for TNF- $\alpha$, IL-6, IL-10 and CRP levels were taken from the subjects in the morning after 12 $\mathrm{h}$ of fasting. Samples were stored at $-20^{\circ} \mathrm{C}$. Serum levels of TNF- $\alpha$, IL-6, IL-10 and CRP were determined by enzyme-linked immunosorbent assay. Primary and biotinylated antibodies against TNF- $\alpha$, IL-6, IL10 were purchased from R\&D Systems Europe (Abingdon, UK). Primary and biotinylated antibodies against CRP were purchased from Dako (Glostrup, Denmark).

For TNF- $\alpha$, IL-6, IL-10, the sensitivity ranged between 2 and $3 \mathrm{pg} / \mathrm{ml}$. For CRP, it was usually 1 $\mathrm{ng} / \mathrm{ml}$.

\section{Statistical analysis}

Statistical analysis was performed by the SPSS for windows (version 10.0) statistical package (SPSS Inc., Chicago, IL, USA). All the numerical variables are presented as mean \pm standard deviation. Because of the abnormal distribution of the data, the means of the two groups were compared with the MannWhitney U-test. If more than two measurements were performed, Kruskal-Wallis one-way variance of analysis was used. If a significant level of $p<0.05$ was found, the values were compared with Wilcoxon signed-rank test. $p<0.05$ was considered significant.

\section{Results}

The CAPD group consisted of 16 patients (nine female, seven male) with a mean age of $41.6 \pm 6.0$ years (range, 17-64 years), whereas the HD group consisted of 14 patients (eight female, six male) with a mean age of $43.0 \pm 8.0$ years (range, $18-66$ years), and the healthy group consisted of 20 patients (11 female, nine male) with a mean age of $42.0 \pm 9.0$ (range, 26-55 years). Patient characteristics and primary renal disease are presented in Table 1 . There was no significant difference between groups regarding age and sex.

The means \pm standard deviations of serum levels and statistical analysis results of CAPD, HD and control groups, at baseline and after 3 months of TNF- $\alpha$, IL-6, IL-10 and CRP are presented in Table 2. There were no differences between and within in the serum TNF- $\alpha$, IL-6, IL-10 and CRP level at baseline and after 3 months in the CAPD and HD groups $(p>0.05)$. However, in CAPD and HD patients the serum TNF- $\alpha$, IL-6, IL-10 and CRP levels were higher than levels in the control group both at baseline and 3 months after treatment $(p<0.001)$. In the CAPD patients no peritonitis episode along the study period was observed.

\section{Discussion}

Chronic uremia is considered a pro-inflammatory state associated with high cardiovascular morbidity and mortality. ${ }^{3}$ Serum IL- 6 and TNF- $\alpha$ were increased in CRF, particularly in dialyzed patients. Compared with controls, IL-6 was elevated in dialysis patients, and TNF- $\alpha$ was elevated in predialysis and dialyzed CRF patients. ${ }^{7}$ CRP levels were increased in CRF and it is thought that this may be an independent risk factor that may cause progressive atherosclerosis. $^{2,8-10}$

Table 1. Subject characteristics and primary diseases of the patients

\begin{tabular}{lccc}
\hline & $\begin{array}{c}\text { CAPD } \\
\text { patients }\end{array}$ & $\begin{array}{c}\text { HD } \\
\text { patients }\end{array}$ & Controls \\
\hline Age (years) & $41 \pm 6$ & $43 \pm 8$ & $42 \pm 9$ \\
Gender (female/male) & $9 / 7$ & $8 / 6$ & $11 / 9$ \\
Primary disease & & & \\
Diabetic nephropathy & 7 & 4 & \\
Chronic glomerulonephritis & 5 & 2 & \\
Hypertensive nephropathy & 2 & 1 & \\
Obstructive nephropathy & 2 & 4 & \\
Polycystic renal disease & - & 2 & \\
Amyloidosis & - & 1 & \\
Total & 16 & 14 & 20 \\
\hline
\end{tabular}


Table 2. Changes in serum CRP and serum cytokine levels in patients with CAPD and HD, and control groups during the study period

\begin{tabular}{lcccc}
\hline & CAPD patients & HD patients & Controls & $p$ value \\
\hline TNF- $\alpha$ baseline $(\mathrm{pg} / \mathrm{ml})$ & $49.7 \pm 24.0$ & $52.8 \pm 26.5$ & $10.7 \pm 3.8$ & $\mathrm{NS}^{\mathrm{a}},<0.001^{\mathrm{b}, \mathrm{c}}$ \\
TNF- $\alpha$ third month $(\mathrm{pg} / \mathrm{ml})$ & $55.6 \pm 27.2$ & $59.0 \pm 28.4$ & & $\mathrm{NS}^{\mathrm{a}^{\prime}}<0.001^{\mathrm{b}, \mathrm{c}}$ \\
IL-6 baseline $(\mathrm{pg} / \mathrm{ml})$ & $8.3 \pm 2.4$ & $8.8 \pm 2.6$ & $3.5 \pm 1.4$ & $\mathrm{NS}^{\mathrm{a}^{\prime}}<0.001^{\mathrm{b}, \mathrm{c}}$ \\
IL-6 third month $(\mathrm{pg} / \mathrm{ml})$ & $9.9 \pm 2.8$ & $9.4 \pm 2.6$ & & $\mathrm{NS}^{\mathrm{a}},<0.001^{\mathrm{b}, \mathrm{c}}$ \\
IL-10 baseline $(\mathrm{pg} / \mathrm{ml})$ & $79.0 \pm 28.6$ & $82.6 \pm 33.5$ & $18.0 \pm 7.0$ & $\mathrm{NS}^{\mathrm{a}^{\prime}}<0.001^{\mathrm{b}, \mathrm{c}}$ \\
IL-10 third month $(\mathrm{pg} / \mathrm{ml})$ & $82.5 \pm 30$ & $84.2 \pm 34$ & & $\mathrm{NS}^{\mathrm{a}^{\prime}}<0.001^{\mathrm{b}, \mathrm{c}}$ \\
CRP baseline $(\mathrm{ng} / \mathrm{ml})$ & $6.1 \pm 4.3$ & $6.0 \pm 4.7$ & $1.6 \pm 1.0$ & $\mathrm{NS}^{\mathrm{a}^{\prime}}<0.001^{\mathrm{b}, \mathrm{c}}$ \\
CRP third month $(\mathrm{ng} / \mathrm{ml})$ & $6.7 \pm 3.5$ & $7.2 \pm 3.8$ & & $\mathrm{NS}^{\mathrm{a}^{\prime}}<<0.001^{\mathrm{b}, \mathrm{c}}$ \\
\hline
\end{tabular}

NS, not significant. ${ }^{a}$ CAPD versus HD, ${ }^{b}$ CAPD versus control group, ${ }^{c}$ HD versus control group.

In these studies, it was observed that the serum CRP levels were significantly increased in the subjects who were treated with hemodialysis and peritoneal dialysis. ${ }^{9,10}$ In cases prior to dialysis, the levels of serum CRP and acute phase protein were found to be related with an increase in the intima-media surface of the carotid artery, and other positive and negative acute phase reactants such as albumin, fibrinogen Apo A-1 and Lp. Serum amyloid A levels were correlated with CRP and some of these proteins may be an additional predictor and/or reasonable factor considering high cardiovascular risk in both HD and peritoneal dialysis patients. ${ }^{2,3,8,9}$ In the present study we found wide variability of CRP and TNF- $\alpha$, IL- 6 and IL-10 even in stable CAPD and HD patients without signs of infection. Serum TNF- $\alpha$, IL6, IL-10 and CRP levels in the CAPD and HD patients were higher than those in the control group at to the beginning values and after 3 months of treatment. However, there were no differences between and within the serum TNF- $\alpha$, IL-6, IL-10 and CRP levels at baseline and after 3 months in CAPD and HD patients.

CRP levels in the present study (averaging $2.0 \mathrm{mg} /$ dl) are higher than in some previous studies for stable CRF patients without signs of infection. In the literature a wide range of CRP levels in CRF patients are reported. Docci et al. observed CRP levels of 7.4 $\mathrm{mg} / \mathrm{dl}$ in dialysis patients, ${ }^{9}$ and Zimmermann et al. reported that the increase in the CRP levels was 46\% in hemodialysis patients. ${ }^{10}$ Owen and Lowrie reported that this increase was 35\%. ${ }^{11}$ The reason why the ratio of the CRP increase is high in the CAPD group is probably that the inflammation in the CAPD patient can be exaggerated both by the peritoneal irritation and the decrease in the removal of the cytokines because of the decrease in the residual renal functions. ${ }^{12}$

Thus, it seems that an individual baseline CRP level can be established for each patient and these levels appear to be well distinguishable between subjects. If these levels reflect the inflammatory state for each individual, they may also predict the cardiovascular risk, as reported for large populations. ${ }^{13,14}$ However, to establish these individual baseline levels, at least three measurements of plasma levels of CRP in the absence of an acute illness appear to be necessary. Macy et al. reported inter-individual variation of $92.5 \%$ and intra-individual variation of $42.2 \%$ for CRP plasma levels in 26 healthy blood donors over a 6-month period, ${ }^{15}$ compared with $88 \%$ and $51 \%$ in the present study. Thus, the variation of CRP is similar in normal subjects and HD patients, although the mean CRP levels are much higher in HD patients (2 $\mathrm{mg} / \mathrm{dl}$ versus $0.17 \mathrm{mg} / \mathrm{dl}$ ). Assuming that a patient's baseline inflammation really predicts cardiovascular risk, the ideal marker of this level should not be shown, but it appears that for acute-phase proteins multiple measurements are needed to assess cardiovascular risk in CRF patients.

In conclusion, we found that serum CRP and some cytokine levels were higher in CAPD and HD patients compared with control subjects. However, renal replacement therapies have no effects on serum CRP and cytokines levels within a 3-month period.

\section{References}

1. Foley RN, Parfrey PS, Sarnak MJ. Epidemiology of cardiovascular disease in chronic renal disesase. J Am Soc Nephrol 1998; 9 (Suppl): 16-23.

2. Eikelboom JW, Hankey GJ. Associations of homocysteine, C-reactive protein and cardiovascular disease in patients with renal disease. Curr Opin Nephrol Hypertens 2001; 10: 377-383.

3. Stompor T, Pasowicz M, Sullowicz W, et al. An association between coronary artery calcification score, lipid profile, and selected markers of chronic inflammation in ESRD patients treated with peritoneal dialysis. Am J Kidney Dis 2003; 41: 203-211.

4. Mendall MA, Patel P, Asante M, et al. Relation of serum cytokine concentrations to cardiovascular risk factors and coronary heart disease. Heart 1997; 78: 273-277.

5. Bevilacqua MP. Endothelial-leukocyte adhesion molecules. Annu Rev Immunol 1993; 11: 767-804.

6. Bonomini M, Reale M, Santarelli P, Stuard S, Settefrati N, Albertazzi A. Serum levels of soluble adhesion molecules in chronic renal failure and dialysis patients. Nephron 1998; 79: 399-407.

7. Bolton CH, Downs LG, Victory JG, Dwight JF, Tomson CR, Mackness MI Pinkney JH. Endothelial dysfunction in chronic renal failure: role of lipoprotein oxidation and pro-inflammatory cytokines. Nephrol Dial Transplant 2001; 16: 1189-1197.

8. Boenisch O, Ehmke KD, Heddergott A, Naoum C, Frei U, Schindler R. C-reactive-protein and cytokine plasma levels in haemodialysis patients. J Nephrol 2002; 15: 547-551.

9. Docci D, Bilancioni R, Buscaroli A, et al. Elevated serum levels of C-reactive protein in haemodialysis patients. Nephron 1990; 56: 364367.

10. Zimmermann J, Herrlinger S, Pruy A, Metzger T, Wanner C. Inflammation enhances cardiovascular risk and mortality in haemodialysis. Kidney Int 1999; 55: 648-658.

11. Owen WF, Lowrie EG. C-reactive protein as an outcome predictor for maintenance haemodialysis patients. Kidney Int 1998; 54: 627-636. 
12. Dikow R, Adamczak M, Henriquez DE, Ritz E. Strategies to descrease cardiovascular mortality in patients with end-stage renal disease. Kidney Int 2002; 61 (Suppl 80): 5-10.

13. Bayes B, Pastor MC, Bonal J, et al. Homocysteine, C-reactive protein, lipid peroxidation and mortality in haemodialysis patients. Nephrol Dial Transplant 2003; 18: 106-112.

14. Haverkate F, Thompson SG, Pyke SD, Gallimore JR, Pepys MB. Production of C-reactive protein and risk of coronary events in stable and unstable angina. European Concerted Action on Thrombosis and Disabilities Angina Pectoris Study Group. Lancet 1997; 349: 462- 466.
15. Macy EM, Hayes TE, Tracy RP. Variability in the measurement of Creactive protein in healthy subjects: implications for reference intervals and epidemiological applications. Clin Chem 1997; 43: 52-58.

Received 16 February 2004

Accepted 18 March 2004 


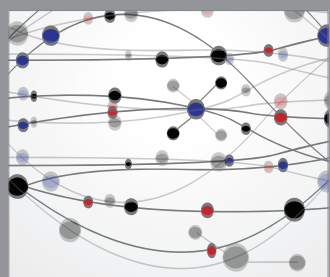

The Scientific World Journal
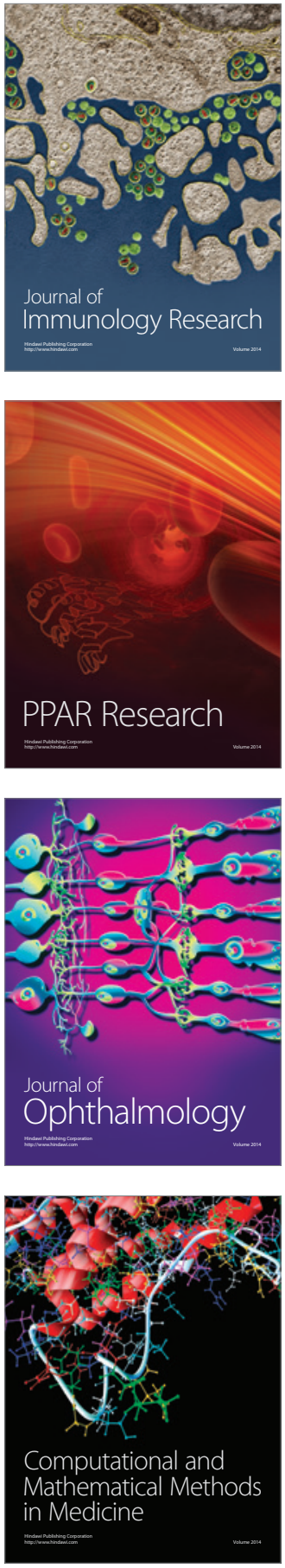

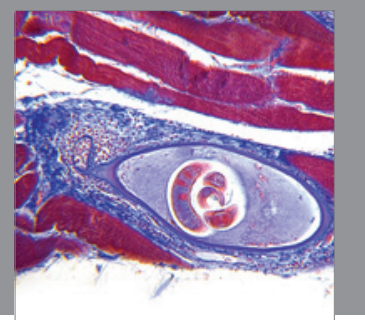

Gastroenterology

Research and Practice
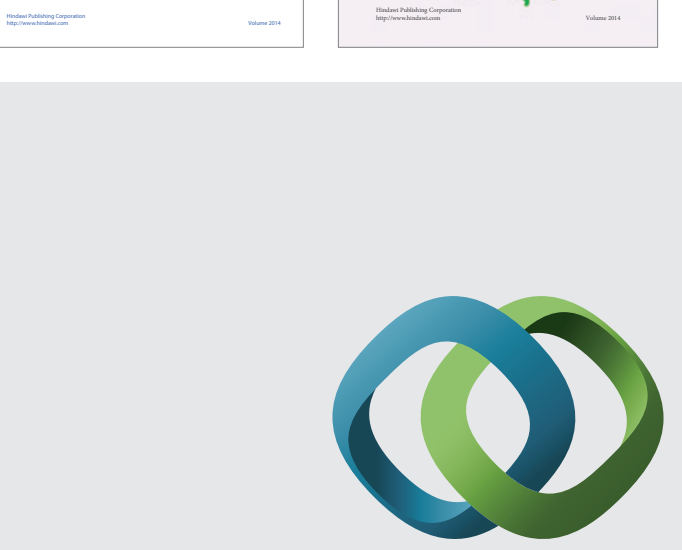

\section{Hindawi}

Submit your manuscripts at

http://www.hindawi.com
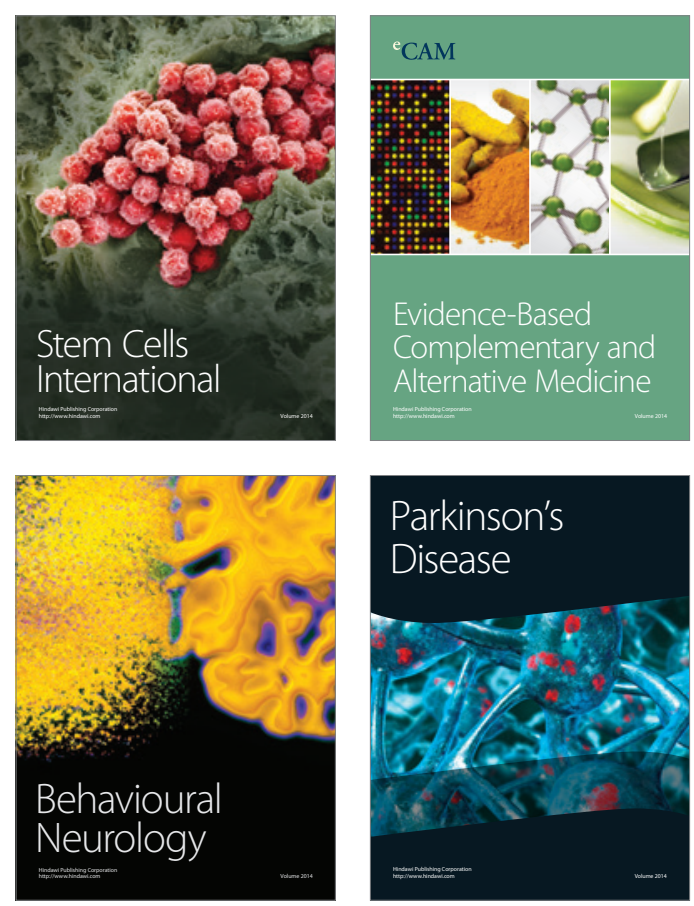

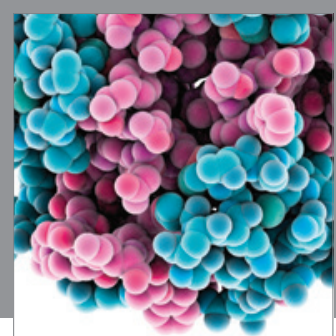

Journal of
Diabetes Research

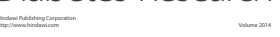

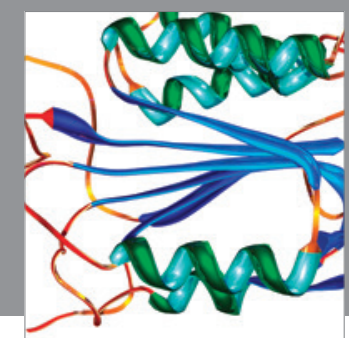

Disease Markers
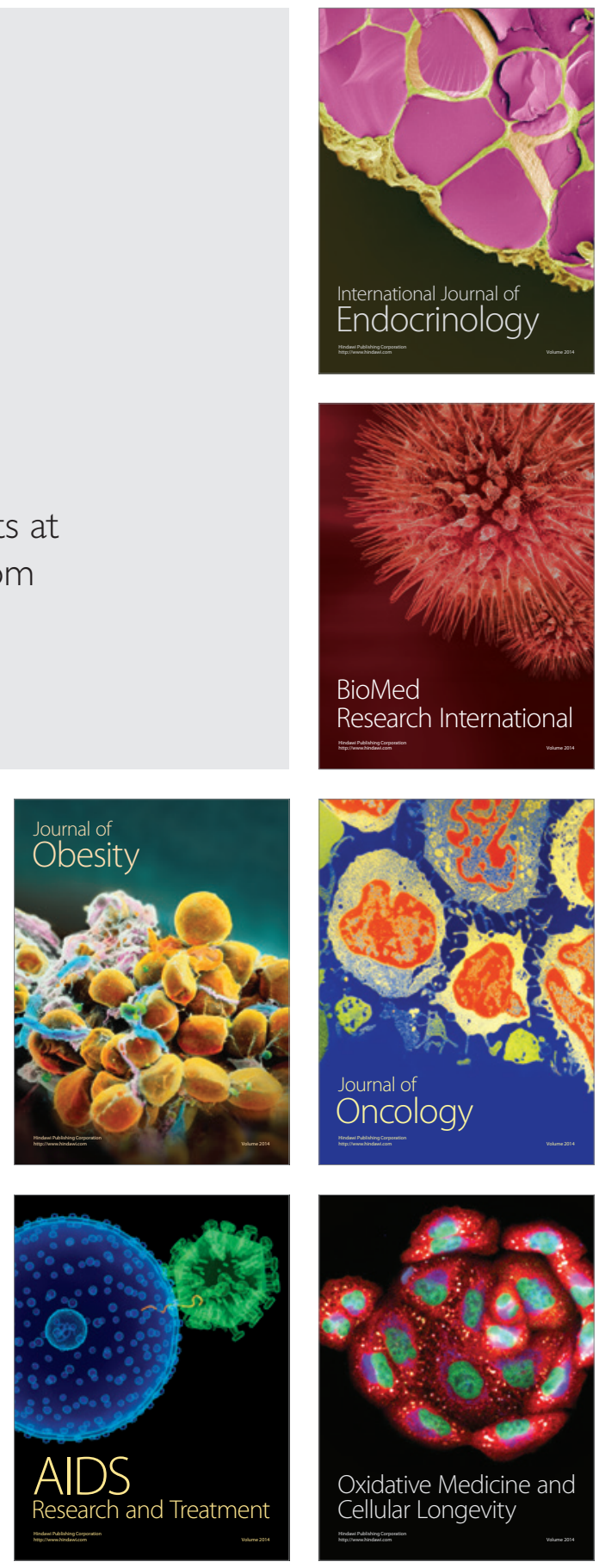